\title{
From Ethnocentrism to Intercultural Communication: The Hundred-Foot Journey
}

\author{
Mu-Hsin Lin ${ }^{1} \quad$ Ya-huei Wang ${ }^{1,2 *}$ \\ 1. Department of Applied Foreign Languages, Chung-Shan Medical University \\ 2.Department of Medical Education, Chung-Shan Medical University Hospital \\ No. 110, Sec. 1, Jian-Koa N. Rd, Taichung, Taiwan
}

\begin{abstract}
This study intends to use the lens of ethnocentrism to analyze how people from different ethnic cultures - in this case, the French culture and Indian culture - fail to communicate with each other and experience a collision of culture related to ethnocentrism. The hundred-foot journey is not just the distance between two restaurants. It is the distance of two ethnic groups and two cultures. To be more culturally relative, there is a need for intercultural communication competence to help people transform themselves from being ethnocentric to culturally relativistic, a journey to remove one's own cultural superiority and to understand the cultural practices of other ethnic groups in terms of their own ethnic cultural contexts.
\end{abstract}

Keywords: ethnocentrism; cultural-relativism; intercultural communication; intercultural sensitivity

DOI: $10.7176 /$ JLLL/56-05

Publication date:May $31^{\text {st }} 2019$

The film The Hundred-Foot Journey (Hallström, 2014) is an American comedy film, based on the novel of the same name by Richard Morais (2010). The film mainly follows an Indian family (the Kadam family) who used to have a popular restaurant in their hometown of Mumbai. The protagonist, Hassan (Manish Dayal), is the main cook at the restaurant, and he learned to cook from his beloved mother. However, due to a riot, they lost everything, including their restaurant — and Hassan's mother lost her life. Under the circumstances, the Kadam family had no choice but to leave their country and look for another place to reopen the restaurant. Upholding the faith of "Wherever the family is, that is the home" (The Hundred-Foot Journey, Hallström, 2014, 10:00), they went to London at first and finally decided to stay at San Antonin, in southern France.

However, the process of reopening their restaurant does not go as smoothly as they expected. On the contrary, a lofty French restaurant is their competitor, operated by Madame Mallory (Helen Mirren). This highclass French restaurant, Le Saule Pleureur, is just one hundred feet across from their Indian restaurant, Maison Mumbai.

At the beginning, the Kadam family does not get along well with the French people; both restauranteurs, especially Papa (Om Puri) and Madame Mallory, try everything they can to humiliate each other, and they despise each other's cultural cuisines. However, Hassan somehow finds himself becoming attracted to the beauty of French food. In order to learn French cuisine, Hassan, with the help of Marguerite (Charlotte Le Bon), who later becomes his girlfriend, has a chance to work for Madame Mallory. Attempting to integrate Indian and French ingredients into fusion cuisine, Hassan creates innovative dishes and helps Madame Mallory's French restaurant achieve two Michelin stars, which has been the lady's lifelong desire. This achievement brings Hassan fame and an invitation to work for another Michelin restaurant, La Baleine Grise, where Hassan learns more "experimental food combinations" (Hallström, 2014, 1:36:57), using different culinary traditions. Although Hassan wins fame for the innovation of his intercultural culinary skills, he finally decides to return to San Antonin to pursue his own dreams of delicacy with his family and his lovely girlfriend, Marguerite.

The main purpose of the study is to use the lens of ethnocentrism to analyze how people from different cultures - in this case, the French and Indian cultures - fail to get along with each other due to culture collisions related to ethnocentrism. Furthermore, the study intends to reveal how intercultural communication can help different ethnic groups transform from being ethnocentric to culturally relativistic, a journey to remove one's own cultural superiority and make sense of other ethnic groups' cultural practices in terms of their own cultural contexts.

\section{CULTURAL SCHEMAS}

Members of a cultural group communicate with each other through their shared collective experience, knowledge, or thought, which are called cultural schemas (Malcolm \& Sharifian, 2002). According to Shore (1996), cultural schemas can be represented through visual arts, rituals, languages, or even the use of silence. Because cultural schemas refer to conceptual structures shared by the members of certain ethnic groups, based on their common experiences and thoughts, the schemas can help the members of ethnic groups to identify and understand each other without difficulty. In other words, communication that draws on the same cultural schemas can facilitate intracultural communication while hindering intercultural communication. Therefore, in 
order to adapt to a new cultural environment, as in the case of new ethnic settlers entering an unfamiliar or novel culture, for instance, culture schemas may serve as a guide for intercultural communication (Nishida, 1999). In other words, when used cleverly, cultural schemas can enable new ethnic settlers to make sense of other cultures, thereby further modifying their behavior in intercultural settings (Rentsch, Gunderson, Goodwin, \& Abbe, 2007).

With respect to the food culture in the film The Hundred-Foot Journey, the beauty and the tasty-looking exotic delicacies are very impressive to the audience. Enjoying delicious food has always been a great pleasure in people's daily lives; yet, various types of races or ethnic groups have different food cultures. Each culture has its own unique cultural schemas; hence, there should be considerable cultural differences among ethnic groups and races. However, it is undeniable that, occasionally, we may feel culturally superior to other cultures, which could have a negative effect on the world. Because people coming from different cultural backgrounds have become accustomed to different values, thoughts, behaviors, and so forth in order to facilitate intercultural communication, there comes a need for intercultural awareness and sensibility between different ethnic groups, which is also a key point of the film The Hundred-Foot Journey.

\section{CULTURAL FOOD PREFERENCE}

There is great variation between the food cultures of France and India and among those of different social groups. However, people tend to determine whether the cuisine is good or not through their own knowledge or experience of food culture. Any deviation from their codes of food culture would be deemed inferior or bizarre (Dasgupta, 2004). Thus, the interpretation of different food cultures based on one's own culture may lead to the preference of an ingroup food culture and a bias toward different food cultures. In The Hundred-Foot Journey, Mansur says to his Papa that "in case you didn't realize it, the French don't even eat Indian food. They have food of their own. It is famous all over the world" (Hallström, 2014, 10:15-10:25). This comment implies that French people take pride in their cuisine.

\section{French Food Culture}

French food has been credited as modern cuisine in the western world (Ferguson, 2004; Mennell, 1996; Trubek, 2000). After Bastille Day in 1789, obtaining grains, the main food of the French, became more and more difficult. With the desire to alleviate hunger and pursue liberty, equality, and fraternity, the French Revolution took place, and many cooks from aristocratic households opened restaurant themselves, beginning to sell tasty food at a reasonable price in order to share fine French cuisine with others.

The table manners within the French food culture are very complicated and lengthy because French people eat not only to fill their stomachs, but also to represent an attitude toward life (Kittler, Sucher, \& Nelms, 2011). Unlike people in some Asian countries, who use chopsticks, French people usually use plenty of tableware and sit at a long table during a meal. The host and hostess are seated at the head and foot of the table, on the short ends, and that the guests are arranged between them, lengthwise (Zili, 2017). The dishes are served in order, and previous dishes are removed as the next course is served. The tableware is placed in a certain order, positioned on both sides of the plate; the utensils are used in order, from the outside to the inside. The first course is usually a soup, followed by a cold dish, then a plat de résistance, and finally, a dessert. Cheese, bread, and wine are almost indispensable at each meal (Flandrin, 2007).

Unlike Indian food, which contains many spices, the decline of medieval ideas regarding food and health has led French food to move away from using excessive spices and sweet and sour flavors; instead, it focuses on the use of raw materials, basic mixtures seasoned with butter and cream, and new culinary skills (Pitte, 2002).

There are five basic sauces in French food: bechamel, veloute, hollandaise, tomato, and espagnole. They are also called the "mother sauces" (Mansfield, 2016) because they are essential for the extension of other sauces, that is, the "daughter sauces." The common spices used in French cuisines are thyme, rosemary, laurel, parsley, tarragon, nutmeg, saffron, cloves, and so forth. The dressing can be used in numerous dishes, like grenouille, coq au vin, escargot, confit de canard, and so forth (Edelstein, 2011). Being a French ingroup member, Marguerite is proud of her French cuisine and her French culinary skills, as shown in the following excerpt.

Marguerite: Uh, I was 12, and I started with the five basics, which is bechamel, veloute, hollandaise, tomato, espagnole. You have to master those five basic sauces first.

Hassan: And you can find all five in the books?

Marguerite: Of course, but they're no use in books. You must find them in your heart, and then bring them to your pots. That's the secret. (Hallström, 2014, 44:16-44:26)

\section{Indian Food Culture}

Indian food is special, and it is deeply influenced by religion. Beef is forbidden among the Hindus (Barak-Erez, 2010; Harris, 1978), but milk is available. For Muslims, pig is not clean, so they refuse to eat pork (Barak-Erez, 2010). People who have a strong belief in either of these two religions are vegetarian. Moreover, because the people have a history of being colonialized by the Portuguese, Persian, and British, these colonial food schemas 
also have a great influence on the Indian food culture (Zubaida, 2009).

Since most Indian cuisine has a large amount of fresh spices and juice, the best way to enjoy Indian dishes is to eat the food with rice, roti, charpati, or naan. Another feature is the colorful display of Indian food, most of which is quite pasty. It is normal to add edible food coloring to a dish to make the food more attractive. Thus, people serve yellow soup, green paste, or red smashes. Water is regarded as the best drink; they always have a glass of ice water on the table when enjoying Indian dishes (Hegde, Nair, Chandran, \& Irshad, 2018).

The traditional method of eating Indian food is by using one's hands and sitting on the floor cross-legged. Indeed, some Indians still eat their local food with their hands instead of using knives, spoons, forks, or chopsticks at home. However, eating with the left hand is strictly prohibited, as they think the left hand is unclean and is, in fact, offensive (SBI, 2006). Indians think using the fingertips to touch food can stimulate the agni (digestive fire) to secrete juices for digestion (Hegde, Nair, Chandran, \& Irshad, 2018). In addition, they believe that touch is the only connection that can be made with not only the senses, but also the mind (Hegde, Nair, Chandran, \& Irshad, 2018; SBI, 2006).

Generally speaking, curry leaves a strong impression with foreigners. Indeed, curry can represent India's food culture to some degree. The curry powder is usually comprised of more than 20 spices, including pepper, turmeric, fennel, and any other secret spices in the family. In The Hundred-Foot Journey, as an Indian cook, Hassan is proud of Indian cuisine and the Indian food culture, especially Indian curry. While Hassan talks about curry enthusiastically to Madame Mallory, saying, "The specials, they will change from day to day" (Hallström, 2014, 31:37), as part of an outgroup, Madame Mallory, a French sous chef, sticks to her natural-food cultural codes and, hence, fails to recognize the differences in curry, replying to Hassan, "Mum. Mum. Well, curry is curry, is it not?" (Hallström, 2014, 31:42).

Not fond of Indian cuisine, Madame Mallory cannot realize that there are differences in curry cuisines and curry tastes in different countries. For instance, in contrast to Japan's sweet-tasting curry, Indian curry specializes in the stimulation of spicy, rich flavors (ESDRC, 2003). Even Papa, Hassan's father, is proud of Indian chili, persuading his customers to try it, saying, "You're trying green chili? Let me explain to you. You take a bite, and start chewing it. And take a small bite of the chili, mix it with the food..." (Hallström, 2014, 40:34). As an outgroup member of India, Madame Mallory dislikes the taste of Indian chili, saying it is "the death of good taste in St. Antonio" (Hallström, 2014, 41:07). Similarly, Papa, knowing that his son Hassan intends to learn about French cuisine, sarcastically accuses Madame Mallory: "You deliberately seduced him! You seduced his mind, with your awful, tasteless, empty sauces! With your pitiful little squashed bits of garlic!" (Hallström, 2014, 1:09:35-1:09:46). Madame Mallory replies to Papa, saying, "That is called subtlety of flavor. It's called meanness of spirit!" (Hallström, 2014, 1:09:47).

Those criticizing other ethnic groups' cuisines and cultures based on their cultural codes or schemas may fail to recognize the differences between cultures and lose the ability to appreciate other cultures, hence, leading to cultural bias and, moreover, ethnocentrism.

\section{ETHNOCENTRISM}

Ethnocentrism refers to people regarding their ways of living, behaviors, values, living patterns, ideologies, and religions as the only positive and reasonable cultural schema. With cultural superiority over others, those with ethnocentrism tend to criticize other ethnic groups' living patterns and cultures in comparison with their own ethnic and cultural values and thinking patterns. Sometimes, those ethnocentric people may even regard other ethnic cultures as strange or unethical. According to LeVine and Campbell (1972), in 1906, Sumner first used the term ethnocentrism in his book Folkways to describe those with cultural narrowness, "ethnically centered" (p. 357) people who only accept those culturally alike as ingroup and reject those with different cultures as outgroups. Moreover, they believe that they, the ingroup, are superior to all outgroups; hence, they are the center of all races, as Sumner says that those with ethnocentrism view that their "own group is the center of everything, and all others are scaled and rated with reference to it" (p. 13). According to Herodotus's record (1942), the first instance of ethnocentrism in western history took place when the Greeks met the Persians. The Greeks felt that the Persians should be mastered instead of having their own freedom.

Those who are ethnocentric not only have a preference for the ingroup, but also have a disdain toward the outgroup or the outgroup products, which is what Teo, Mohamad, and Ramayah (2011) call "soft" ethnocentrism. Those with ethnocentrism may have certain food preferences, which is perhaps the most familiar aspect of ethnocentrism. Because each culture has developed certain food cultural schemas, while confronting other cultures, people may hold strong negative attitudes toward or reject others' food cultures. For example, when Hassan brings Madame Mallory a cuisine that he cooked to apologize for his father's rude behavior of buying all the pigeons, Madam Mallory, after tasting one spoonful of the food, throws it into the trash, in front of Hassan, to show her contempt for Indian food (Hallström, 2014, 51:31-52:47).

There is great variation between the food cultures in France and India and among different social groups. People tend to narrowly interpret food and cuisine based on their food cultural schemas, without appreciating the 
diversity of food cultures. Therefore, due to the superiority of their own cuisine and food culture, any deviation from their culture may be regarded as bizarre or inferior. Thus, with one's own cultural superiority over others, those who are ethnocentric lose the chance to attribute cultural differences and food preferences to differences in ethnic cultural schemas. Madam Malloy's throwing the Indian food directly into the trash in front of Hassan indicates that she has no tolerance toward Indian or foreign cultures. Moreover, another scene clearly reveals Madam Malloy's condemnation of Indian behaviors, music, cuisine, products, and cultures.

Madam Mallory: You may like this kind of music, but the rest of the village does not.

Papa: $\quad$ Sorry, madam. Welcome to our humble abode, Madame, and thank you for barging in.

Madam Mallory: I knocked, but you couldn't hear me, because the music was so loud.

I, um, just came to see how things are coming along.

Papa: Well, we are doing pretty well.

Madam Mallory: Mmm. What is this?

Mansur: It is an oven.

Madame Mallory: Oven? It's not a drum? To play?

Mansur: No. Tandoor oven for chicken tikka. Sometimes small children. Joking.

Madame Mallory: Plastic.

Papa: Did you get my invitation to our opening night on Saturday?

Madame Mallory: Oh, yes, yes, of course. But Saturdays we are very, very busy.

Papa: $\quad$ Oh, I see.

Madame Mallory: Um, but could I look at a menu?

Hassan: $\quad$ Yes. Of course. Uh...Relax, Papa. Right. This is our menu. The specials, they will change from day to day.

Madame Mallory: Mmm. Mmm. Well, curry is curry, is it not?

Papa: $\quad$ Obviously you've never eaten Indian food, especially cooked by my son.

Madame Mallory: Yes, I understand you people like to keep everything in the family. Well, if your food is anything like your music, I suggest you turn it down. (Hallström, 2014, 30:19-32:08)

Madame Mallory's perception about Indian culture is that it is inferior and weak. She is annoyed by the noisy music played by Hassan's father, a traditional Indian song that she defines as noise. Furthermore, when looking around the Indian restaurant, Madame Mallory sees an unknown drum-like kitchenware item that has never been used for French food. After learning that it is an oven for Indian cuisine, she makes an ironic and mocking comment about it. With cultural superiority, Madame Mallory keeps looking for and criticizing those which are odd to her. While comparing the plastic tablecloth used in the Indian Maison Mumbai restaurant to the cloth tablecloth in her high-ranked French Le Saule Pleureur restaurant, Madame Mallory dismisses their plastic tablecloths as vulgar customs. Moreover, when leaving the Indian restaurant, Madam Mallory insults his Indian music and his food (Hallström, 2014, 32:08). These sarcastic words stem from her ethnocentrism, her cultural superiority over Indians.

Generally speaking, ethnocentrism features an inflexible, strict distinction between internal groups and external groups (LeVine \& Campbell, 1972). Ethnocentric people hold a positive bias toward their ingroup and cultural norms, hence, developing a negative bias toward outgroups. Therefore, in insisting on their own cultural schemas and superiority, they reject communication with those outgroups. Mr. Kadam (Papa), for instance, rejects intercultural communication, claiming that the "Indian [will] never become French and [the] French [will] never become Indian" (Hallström, 2014, 1:10:22).

Those who have ethnocentrism are accustomed to their cultural schemas, and therefore, while evaluating other ethnic groups' cultures based on their own cultural codes, they would think the outgroups' cultural schemas are not acceptable. With such cultural superiority, ethnocentric people often generate negative prejudices and hostile attitudes toward outgroup members. Moreover, because they are not open-minded, they refuse to recognize other ethnic cultures. Consequently, the door of intercultural communication is shut.

Furthermore, being extremely ethnocentric, people may hold not only hostility, but also discrimination toward outgroup members. Those being discriminated against may also seek revenge for the discrimination or hostility against them. For example, on the opening day of their new restaurant, Papa and Hassan go to a market to buy ingredients for their Indian cuisine and wonder why all of the ingredients they need are sold out: "All the capes are sold. Madame Mallory purchased all the mushrooms" (Hallström, 2014, 34:33). Hassan apologizes to Papa for having shown the menu to Madame Mallory. With no ingredients for their Indian cuisine, they must travel to a distant market to buy the ingredients for their opening day. In order to take revenge upon Madam Mallory for her hostility toward them, Papa buys all the pigeons; that way, Madam Mallory will have no pigeons for her special menu. Papa is proud of his action, saying, "Well, she did it to us. I do it to her. War. Papa is smart, yes?" (Hallström, 2014, 51:00). 
According to Samovar, Porter, and McDaniel (2007), ethnocentrism can be conceptualized into three levels: positive, negative, and extremely negative. At the positive level, also a natural phenomenon, people prefer their own ethnic culture over other cultures. At the negative level, people may view their own ethnic culture as dominant and use their cultural norms to evaluate other cultures. However, those who are ethnocentric at an extremely negative level would regard their culture as the dominant culture and expect other ethnic groups to follow their social codes and schemas. Therefore, those with an extremely negative level of ethnocentrism may display competition or stigmatization. Ethnocentric behaviors of stigmatization appear clearly through the actions of one of Mallory's chefs, Jean-Pierre (Clément Sibony).

Jean-Pierre: You know, I saw that Indian guy buying things in the convenience store. His cart was full of cat food. They don't even have a cat. I guess it was for the curry. (Hallström, 2014, 29:06)

Jean-Pierre is totally annoyed by the existence of the Hassan family. Thus, he always creates rumors to offend and humiliate them. The words that he uses to describe Hassan's family are harsh and impolite. Definitely, Jean-Pierre models ethnocentrism. What's worse, Jean-Pierre is so irritated that he decides to devastate their Indian restaurant Maison Mumbai, saying, "The smell of curry: it's everywhere! Honestly! No sense of culture or tradition. And they're staying open tomorrow, on our Bastille Day. It's time to stop them" (Hallström, 2014, 54:50-55:55). Jean-Pierre, calling these Indians "invaders," spray paints the words France for the French on the outer wall of Hassan's restaurant (Hallström, 2014, 58:23).

One of the negative functions of ethnocentrism is that it raises an extreme bias among different races and, to make it worse, causes casualties, as with Jean-Pierre. It is not until he strikes that Madame Mallory realizes that it is not wise to be enemies continuously with those who have diverse ethnic cultures. She tells Jean-Pierre, "There are other ways to be French. Liberty. Equality. Fraternity" (Hallström, 2014, 1:01:13) and "You tell your friends that these bombs have ended a war. They have brought peace" (Hallström, 2014, 1:01:24-1:01:34). The search for liberty, equality, and fraternity is the impetus for the French Revolution. After that event, Madame Mallory starts to show her good intentions to communicate with Hassan's family and to attribute the differences between her and the Indian Kadam family to the differences in ethnic cultural schemas. At this time, Madame Mallory learns to appreciate Indian culture, as well as Indian cuisine.

With cultural superiority in mind, people may tend to judge other ethnic cultures based on their own cultural ideals and become ethnocentric. To avoid the notion of ethnocentrism, people should learn to judge other races in terms of their cultures, that is, cultural relativism.

\section{CULTURAL RELATIVISM \& MULTICULTURAL COMMUNICATION}

Ethnocentrism refers to the idea that people judge another culture based on their culture's values and schemas, instead of using the other ethnic groups' cultural norms to criticize their values, behaviors, and so forth (Neuliep, 2009). However, there are many ethnic groups and ways of living styles; thus, there are many ethnic cultures. Since it is impossible to prove that certain ethnic cultures are superior to others, there is a need for mutual respect for each other. However, respecting others' practices requires more than just tolerance. Cultural relativism requires a respect for cultural differences. However, cultural respect through tolerance is not enough; an understanding of the outgroup members' values, thinking, behaviors, and so forth through their cultural schemas and cultural contexts is also required (Reidel, 2010).

Cultural relativism is often interchangeably used with multiculturalism, a synonym of ethnic pluralism. Due to internationalization and globalization, interactions among different cultures have become more and more frequent, leading to a combination of different cultures. To understand different ethnic groups, there is a need for intercultural communication in order to facilitate a positive communication between different races and cultures. Multiculturalism is also termed as "salad bowl" and "cultural mosaic" (p. 78), which implies the integration of different cultures (Boyd \& Walter, 2012). While ethnocentrism refers to the idea that certain cultures are superior to others (Nanda \& Warms, 1998), the idea of cultural relativism or multiculturalism declares that all different cultural ethnicities have equal rights. No one is more dominant or inferior. Bennett (2004) implies that those ethnocentric individuals have a lower level of intercultural competence. Therefore, in order to be culturally relativistic, there is a need for intercultural competence to facilitate intercultural communication (Neuliep, Hintz, \& McCroskey, 2005)

Madame Mallory's willingness to bring peace and show her goodwill to Hassan's family is a turning point, leading the extremely negative level of ethnocentrism to a cultural relativism, a facilitation of multiculturalism. The first idea of multiculturalism comes from Hassan. Hassan is the first one willing to cross the border and experience French cuisine to facilitate intercultural communication, attempting to understand human experiences in different ethnic cultural schemas (Arent, 2009). Moreover, with his mutton dish, Hassan tries to use red wine, which is typically used in French cuisine, not Indian cuisine.

Mansur: Hassan, now we won't have enough time to cook the mutton properly. We should just take it off the menu, yeah? 
Hassan: No. Rest it in a little red wine, and add crushed cardamom.

Mansur: Wine? We don't use wine.

Hassan: This is an emergency, Mansur. Wine will flavor the meat. When in Rome.

Mansur: Yeah, well, we're not in Rome, are we?

Hassam: Mansur, to survive here, we're going to need to adapt. We have to make use of what is close to us. Then we pray to God that it works. (Hallström, 2014, 36:06)

According to what Hassan introduces about Indian cuisine, wine is not a seasoning included in traditional Indian food. Mansur's (Amit Shah) opinion is a case of ethnocentrism. Mansur considers that it is unusual to add red wine to Indian cuisine. On the contrary, from Hassan's point of view, there is no specific way to improve a dish. It could be by either spending more time on cooking the mutton or just resting it in the wine, adding crushed cardamom would flavor the meat. The reason why Hassan suggests using red wine in Indian cuisine is that, after acquiring French culinary knowledge and skills, he has become stimulated and more open-minded toward combining French and Indian food cultures to create more intercultural and delicious cuisine. Hence, Hassan somehow uses his own method to surmount the cultural barrier and lead the way to multiculturalism. If Hassan's and Madame Mallory's restaurants are models of society, Hassan endeavors to reach multiculturalism or cultural pluralism, in which people in different ethnic groups can work together and enter into a dialogue with each other, however not sacrificing their ethnic identities. Willing to partake in intercultural communication, both Madame Mallory and Hassan's father finally relinquish their pride and overcome their disagreements. They start to cooperate and understand each other.

Also, after being hired by Madame Mallory, Hassan works passionately to help the French restaurant Le Saule Pleureur achieve two Michelin stars, which has always been the lady's lifelong desire. Hassan becomes a well-known and popular chef, and a famous and stylish restaurant in Paris, called Baleine Grise, decides to hire him, allowing Hassan to acquire practical techniques "for experimental food combination" (Hallström, 2014, 1:36:57) whereby he can integrate Indian and French ingredients and different culinary traditions in a fusion cuisine.

La Baleine Grise has always been known for experimental food combinations. But on my most recent visit, the oysters with nitro pearls of sturgeon and oyster dust were made exceptional by the addition of ground cardamom seeds. Cardamom. While it's only been a few months since my last visit, I was pleasantly surprised by the appearance of coriander, fenugreek and masala.

Glutinous sauce resonant of tandoori. This was a surprising triumph.

The most unexpected ways. With a marinade of tamarind and smoked chili, the fish swims into my top five of all time. It's sugarcoated beetroot with carrots, also garam masala.An established molecular cuisine favorite in Beaubourg appears to have discovered the spice of life.

Cauliflower ice cream with a skim of egg yolk and capers. (Hallström, 2014, 1: 36:57$1: 37: 59$; in narration)

Being open-minded, Hassan embraces different food cultures, in this case, French and Indian cuisines, to bring innovation to the spirit of food. When Hassan incorporates different food cultures into his cuisines, he develops his cooking potential and innovation, allowing him to present the art of food, a cuisine based on multicultural communication.

Moreover, Hassan's innovative combination of different ingredients and culinary traditions from different ethnicities impresses food critics and receives a great response. Hassan's ability to create an innovative intercultural cuisine symbolizes intercultural communication competence: intercultural communication awareness and intercultural communication sensitivity (Qingweng, Day, \& Collaço, 2008). Hence, Hassan may be aware of biased ethnocentric ideas and be more sensitive to other ethnic cultures, since he transformed himself from being more ethnocentric to being more ethno-relative or culturally relative. Instead of ignoring cultural differences and rejecting others' existence, Hassan learns to realize and further appreciate cultural differences, bringing innovation to intercultural or transcultural cuisine.

\section{THE HUNDRED-FOOT JOURNEY: FROM ETHNOCENTRISM TO INERCULTURAL COMMUNICATION}

It is natural for people to be afraid of something unfamiliar. Moreover, some people will erect defensive attitudes or behaviors to protect themselves from being invaded by unknown ethnic cultures. However, this is not a correct attitude when facing a new ethnic culture or unfamiliar ethnic group. The film The Hundred-Foot Journey presents the natural and authentic reaction of people who meet unknown ethnic cultures or groups, showing that they may at first resist each other's cultures. However, with intercultural communication awareness and intercultural communication sensitivity, people may be willing to cross the border and care about each other's cultural schemas. Although Madame Mallory's French restaurant (Le Saule Pleureur) is just one hundred 
feet across from Papa's Indian restaurant (Maison Mumbai), Madame Mallory and Papa take a much longer journey to cross the border between being ethnocentric and being culture-relative.

The one-hundred-foot journey is not merely the distance of these two restaurants: it is the distance of two ethnic groups and two cultures. Although the distance of one hundred feet is not long, it is not easy to cross the border without intercultural communication awareness and intercultural communication sensitivity. The onehundred-foot journey is a journey from ethnocentrism to culture relativism, a journey to release one's own cultural superiority and attempt to make sense of the cultural practices of other ethnic groups in terms of their own ethnic cultural contexts.

\section{REFERENCES}

Alfaro, D. (2019). Five mother sauces of classical cuisine. https:/www.thespruceeats.com/mother-sauces996119.

Arent, R. (2009). Bridging the cross-cultural gap. MI: University of Michigan Press.

Bennett, M. J. (2004). Becoming interculturally competent. In J. Wurtzel (Ed.), Toward multiculturalism: A reader in multicultural education ( $2^{\text {nd }}$ ed.) (pp. 62-77). Newton, MA: Intercultural Resource Corporation.

Bennett, J. M., \& Bennett, M. J. (2004). Developing intercultural sensitivity: An integrative approach to global and domestic diversity. In D. Landis, J. Bennett \& M. Bennett (Eds.), Handbook of intercultural training $\left(3^{\text {rd }}\right.$ ed, pp. 147-165). Thousand Oaks: Sage.

Barak-Erez , D. (2010). Symbolic Constitutionalism: On Sacred Cows and Abominable Pigs. Law, Culture and the Humanities, 6(3) 420-435.

Dasgupta, S. (ed.) 2004. The changing face of globalization. New Delhi: Sage Publications.

Edelstein S: (2011). Food, cuisine and cultural competency for culinary, hospitality and healthcare professionals. MA: Sudbury.

ESDRC (2003). Let's visit the world of the curry! Diversity of spices and food cultures. Tokyo: Education for Sustainable Development Research Center.

Ferguson, P. P. (2004). Accounting for taste: The triumph of French cuisine. Chicago: The University of Chicago Press.

Flandrin, J. L. (2007). Arranging the meal: a history of table service in France. CA: University of California Press.

Franklin, R. (2018). The ancient French diet: A brief history and timeline of French food. https://www.thespruceeats.com/history-of-french-food-1375346. Accessed 12 September. 2018.

Hallström, L. (2014). The Hundred-Foot Journey. Burbank, CA: Walt Disney Studios Motion Pictures.

Harris, M. (1978) India's Sacred Cow. Human Nature, 1(2), 28-36.

Hegde, S., Nair, L. P., Chandran, H., \& Irshad, H. (2018). Traditional Indian way of eating--an overview. Journal of Ethnic Foods. 5(1), 20-23.

Herodotus (1942). The Persian wars. Trans. G. Rawlinson. New York: Random House.

Kittler, P. G., Sucher, K. P., Nelms, M. (2011). Food and Culture. 6th ed. Belmont, CA: Wadsworth; 2011.

LeVine, R. A., \& Campbell, D. T. (1972). Ethnocentrism: Theories of conflict, ethnic attitudes, and group behavior. New York: John Wiley \& Sons.

Lipset, D. (1993). Review: Culture as a hierarchy of schemas. Current Anthropology, 34(4), 497-498.

Malcolm, I. G. \& Sharafian, F. (2002). Aspects of aboriginal English oral discourse: An application of cultural schema theory. Discourse Studies, 4, 169-181.

Mansfield, C. (2016). French Food. https://www.researchgate.net/publication/320871051_French_Food. Accessed 15 September. 2018.

Mennell, S. (1996). All manners of food: Eating and taste in England and France from the middle ages to the present. Urbana and Chicago: University of Illinois Press.

Nanda, S., \& Warms, R. L. (1998). Cultural anthropology (6th ed). Belmont, CA: Wadsworth.

Neuliep, J. W. (2009). Intercultural communication: A contextual approach (4th ed.). Thousand Oaks, CA: Sage.

Neuliep, J. W., Hintz, S. M., \& McCroskey, J. C. (2005). The influence of ethnocentrism in organizational contexts: Perceptions of interviewee and managerial attractiveness, credibility, and effectiveness. Communication Quarterly, 53(1), 41-56.

Nishida, H. (1999). Cultural schema theory. In W. B. Gudykunst (Ed.), Theorizing about intercultural communication (pp. 401-418). Thousand Oaks, CA: Sage Publications Inc.

Pitte, J. (2002). French gastronomy faced with globalization. Trans by Jennifer J. Moody, Phi Kappa Phi Forum, 82(3), 34-38.

Reidel, L. (2010). What are cultural rights? Protecting groups with individual rights. Journal of Human Rights, $9(1), 65-80$

Qingweng, D., Day, D. K., \& Collaço, C. M. (2008). Overcoming Ethnocentrism through Developing Intercultural Communication Sensitivity and Multiculturalism. Human Communication. A Publication of 
the Pacific and Asian Communication Association. 11(1), 27 - 38.

Rentsch, J. R., Gunderson, A., Goodwin, G. F., \& Abbe, A. (2007). Conceptualizing multicultural perspective taking skills. (TR 1216). Arlington, Virginia: U.S. Army Research Institute for the Behavioral and Social Sciences.

Richard Morais (2010). The Hundred-Foot Journey. New York: Scribner.

Samovar, L. A., Porter, R. E., \& McDaniel, E. R. (2007). Communication between cultures (6th ed.). Belmont, CA: Thomson Wadsworth.

SBI (2019). Indian Etiquette. http://www.a-to-z-of-manners-and-etiquette.com/indian-etiquette.html. Accessed 20 March. 2019.

Scott H. Boyd. \& Mary Ann Walter (2012). Cultural difference and social solidarity: Critical cases. New Castle: Cambridge Scholars Publishing.

Shore, B. (1996). Culture in mind: Cognition, culture, and the problem of meaning. Oxford: Oxford University Press.

Sumner, W. G. (1906). Folkways: A study of the sociological importance of usages, manners, customs, mores, and morals. Boston, MA: Ginn and Company.

Teo, P. C., Mohamad, O., \& Ramayah, T. (2011). Testing the dimensionality of consumer ethnocentrism scale (CETSCALE) among a young Malaysian consumer market segment. African Journal of Business Management, 5(7): 2805-2816.

Trubek, A. (2000). Haute cuisine: How the French invented the culinary profession. Philadelphia: University of Pennsylvania Press.

Zili, X. (2017). The differences of Chinese and Western food cultures. Chinese Language, Literature \& Culture, $2(1), 6-9$.

Zubaida, S. (2009). The idea of "Indian food", between the colonial and the global. Food and History. 7(1). 191209. 